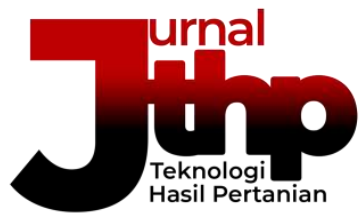

Jurnal Teknologi Hasil Pertanian. 13(2), 94-103

URL: https://jurnal.uns.ac.id/ilmupangan/article/view/43576

DOi: https://doi.org/10.20961/jthp.v13i2.43576

ISSN 1979-0309 (Online) 2614-7920 (Print)

\title{
PENGARUH VARIASI MALTODEKSTRIN DAN KECEPATAN HOMOGENISASI TERHADAP KARAKTERISTIK FISIKOKIMIA ENKAPSULAT BUTTER PALA (Myristica fragrans Houtt) DENGAN METODE VACUUM DRYING
}

\author{
EFFECT OF MALTODEXTRIN VARIATION AND HOMOGENIZATION SPEED BASED ON \\ TO PHYSICOCHEMICAL CHARACTERISTICS OF ENCAPSULATED NUTMEG BUTTER \\ (Myristica fragrans Houtt) USING VACUUM DRYING
}

\author{
Birgitta Devina Santoso, Victoria Kristina Ananingsih, Bernadeta Soedarini, Jessica Stephanie \\ Program Studi Ilmu Teknologi Pangan Fakultas Teknologi Pertanian, Universitas Katolik Soegijapranata, \\ Semarang \\ email: birgittadevina@gmail.com
}

Diserahkan [8 Agustus 2020]; Diterima [17 Agustus 2020]; Dipublikasi [20 Agustus 2020]

\begin{abstract}
Nutmeg plant (Myristica fragrans Houtt.) is one that comes from the Banda Island. Indonesia exports $60 \%$ of the world's nutmeg seeds and mace. Nutmeg butter is one of the ingredients in nutmeg which is produced from the extraction process with hexane solvents using Ultrasound-Assisted Extraction (UAE) at a temperature of $45^{\circ} \mathrm{C}$ for 37.5 minutes. Nutmeg butter has properties that are easily damaged by light and heat, so the encapsulation process is carried out to increase shelf life and selling value. This research was conducted to determine the best combination and effect of maltodextrin variations and homogenization speed in the analysis of water content, water activity, color measurement, and antioxidant activity in nutmeg butter encapsulate. The encapsulation method used is vacuum drying using low pressure with a temperature of $50^{\circ} \mathrm{C}$ for 48 hours. In this research, the coating material used is maltodextrin isolate and whey protein (WPI) as emulsifier (WPI:nutmeg butter = 6:4). The independent variables used were maltodextrin $(M D)($ MD: nutmeg butter $=2: 4,4: 4$, dan 6:4)and homogenization speed (3000, 3500, and $4000 \mathrm{rpm})$. Furthermore, the results of physical property, namely color measurement CIELab and chemical properties, namely moisture content, water activity, and antioxidant activity were then analyzed using SPSS (One Way ANOVA and Duncan). Based on the research, it can be concluded that the optimum nutmeg butter encapsulate formula is at a 2 gram maltodextrin concentration and 3000 rpm homogenization speed. This was chosen because the highest antioxidant activity was 94,598\%, the water content of the encapsulate powder was 7,788\% (according to SNI standards $<12 \%$ ), water activity was 0,626 , and a bright yellow powder color was obtained ( $L *$ value $=88,247, a *$ value $=1,215$, and the value of $b$ $*=25,7)$. The combination of maltodextrin variation with homogenization rate was significantly different $(\alpha$ $<0,05)$ on the physical characteristics of the encapsulate with the color measurement value $b^{*}$ and water activity, but not significantly different $(\alpha>0,05)$ on moisture content and color measurement value $L^{*}$.
\end{abstract}

Keywords: nutmeg butter, encapsulation, vacuum drying

\section{ABSTRAK}

Tanaman pala (Myristica fragrans Houtt.) merupakan salah satu rempah yang berasal dari kepulauan Banda, Indonesia. Butter pala merupakan salah satu kandungan dalam pala yang dihasilkan dari proses ektraksi dengan pelarut n-heksana menggunakan Ultrasound-Assisted Extraction (UAE) dengan suhu $45^{\circ} \mathrm{C}$ selama 37,5 menit. Butter pala memiliki sifat yang mudah rusak oleh cahaya dan panas, sehingga dilakukan proses enkapsulasi untuk meningkatkan umur simpan dan nilai jual. Penelitian ini dilakukan untuk mengetahui kombinasi terbaik serta pengaruh variasi maltodekstrin dan kecepatan homogenisasi pada analisa kadar air, aktivitas air, intensitas warna, dan aktivitas antioksidan pada enkapsulat butter pala. Enkapsulasi dilakukan dengan vacuum drying yang bertekanan rendah dengan suhu $50^{\circ} \mathrm{C}$ selama 48 jam. Dalam penelitian ini digunakan bahan penyalut yaitu maltodekstrin dan whey protein isolate (WPI) sebagai emulsifier (WPI : butter pala $=6: 4)$. Enkapsulasi butter pala dilakukan dengan parameter pembanding yaitu maltodekstrin (MD)(MD : butter pala $=2: 4,4: 4$, dan $6: 4$ ) dan kecepatan homogenisasi (3000, 3500, dan 4000 rpm). Kemudian hasil 
enkapsulat dianalisa secara fisik yaitu pengukuran warna CIELab dan secara kimiawi yakni kadar air, aktivitas air, dan aktivitas antioksidan kemudian dianalisis dengan menggunakan SPSS (One Way ANOVA dan Duncan). Berdasarkan penelitian, maka dapat disimpulkan bahwa formula enkapsulat butter pala optimum yakni pada konsentrasi maltodekstrin 2 gram dan kecepatan homogenisasi $3000 \mathrm{rpm}$. Ini dipilih karena aktivitas antioksidan yang tertinggi didapatkan sebesar 94,598\%, kadar air bubuk enkapsulat 7,788\% (sesuai standar SNI <12\%), aktivitas air 0,626, serta didapatkan warna bubuk kuning cerah (nilai $\mathrm{L}^{*}=88,247$, nilai $\mathrm{a}^{*}=1,215$, dan nilai $\mathrm{b}^{*}$ $=25,7)$. Konsentrasi maltodektrin dengan kecepatan homogenisasi berbeda nyata $(\alpha<0,05)$ terhadap pengukuran warna nilai $b^{*}$ dan aktivitas air, namun tidak berbeda nyata $(\alpha>0,05)$ terhadap kadar air dan nilai warna $\mathrm{L}^{*}$.

Kata Kunci : nutmeg butter; enkapsulasi; vacuum drying

\section{PENDAHULUAN}

Butter pala merupakan salah satu kandungan dalam pala yang dihasilkan dari proses ektraksi dengan pelarut n-heksana menggunakan Ultrasound-Assisted Extraction (UAE). Butter pala berupa cairan semi padat yang aromatik (bau dan rasa khas pala), berwarna kuning-orange, yang berbentuk padat pada suhu ruang dan mencair pada suhu $45-51^{\circ} \mathrm{C}$, memiliki berat jenis 0,990-0,995. Komponen utama dari butter pala adalah trimyristin $(73,09 \%)$ dan minyak atsiri (12,5\%) (Nurdjannah et al., 2007). Butter pala memiliki sifat yang mudah rusak akibat cahaya dan panas, sehingga diperlukan proses enkapsulasi yang bertujuan untuk meningkatan umur simpan (Zhao \& Zhang, 2011). Enkapsulasi adalah suatu proses pembuatan kapsul dengan menggunakan bahan penyalut tertentu. Bahan penyalut yang digunakan harus bersifat sebagai pengemulsi, memiliki daya larut dalam air, kemampuan membentuk film, dan viskositas rendah (Sheu \& Rosenberg, 1998).

Salah satu bahan yang dapat digunakan sebagai pembungkus dari enkapsulasi adalah maltodekstrin, karena memiliki rasa dan aroma yang netral, bersifat mudah larut air, viskositas rendah pada konsentrasi tinggi, memiliki kapasitas pembentukan film, dan perlindungan yang baik terhadap oksidasi bahan inti (Cahyadi, 2017). Berdasarkan penelitian Yuliasari et al., (2016) tentang enkapsulasi minyak sawit merah digunakan pengkapsul dari dua jenis bahan yang berbeda, dan dihasilkan enkapsulat dengan bahan pengkapsul maltodekstrin dengan xanthan gum menghasilkan permukaan kapsul yang halus. Namun, maltodekstrin juga memiliki kelemahan yakni emulsinya kurang stabil, sehingga kemampuan terhadap pemerangkapan butter pala rendah. Oleh karena itu, dibutuhkan bahan pengemulsi agar bahan inti dapat tersalut dengan sempurna. Whey protein isolate (WPI) merupakan salah satu emulsifier yang baik dalam sistem pangan, yang berperan untuk menyatukan antara fase air dan fase minyak. Kombinasi dari maltodekstrin dan whey protein akan menghasilkan stabilitas emulsi yang lebih baik dibandingkan kombinasi antara maltodekstrin dengan pati (Purnomo et al., 2014). Maltodekstrin merupakan karbohidrat yang berfungsi dalam membentuk matriks dan filler, sedangkan whey protein akan membentuk film (Gardjito et al., 2006). Penambahan maltodekstrin berpengaruh pada peningkatan kualitas fisik dan kimia suatu produk. Maltodekstrin yang semakin banyak akan meningkatkan total padatan sehingga memicu penurunan kadar air (Hayati et al., 2015). Warna maltodekstrin yang putih akan meningkatkan kecerahan dalam suatu bahan (Yuliawaty \& Susanto, 2015).

Dalam proses enkapsulasi diperlukan homogenisasi yang bertujuan untuk menyeragamkan dan juga mengecilkan partikel (Muchtadi et al., 2015). Proses homogenisasi merupakan salah satu proses yang berpengaruh dalam pembentukan enkapsulat, dimana semakin cepat homogenisasi maka akan meningkatkan kestabilan dari serbuk yang dihasilkan (Silva et al., 2016). Semakin meningkatnya kecepatan homogenisasi, maka akan terjadi penurunan kadar air akibat viskositas yang semakin tinggi (Silva et al., 2016).

Berdasarkan uraian tersebut, maka perlu dilakukan penelitian tentang kombinasi terbaik dan pengaruh konsentrasi maltodekstrin dan kecepatan homogenisasi pada analisa sifat fisik (intensitas warna) dan sifat kimia (kadar air, aktivitas air, dan aktivitas antioksidan) enkapsulat butter pala dengan menggunakan metode pengeringan 
vakum, membuat penelitian ini menjadi penting. Pengujian antioksidan ini menjadi penting karena pala memiliki kandungan antioksidan alami yang tinggi, sehingga dapat melihat penurunan kualitas antioksidan dari serbuk butter pala. Pengujian fisik dan kimia digunakan untuk melihat kualitas bubuk enkapsulat yang dihasilkan.

\section{METODE PENELITIAN}

\section{Bahan}

Bahan yang digunakan dalam penelitian terdiri dari bahan untuk ekstraksi dan enkapsulasi. Bahan ekstraksi terdiri dari bahan utama yakni biji pala (Myristica fragrans) dari Pasar Jatingaleh Semarang, pelarut $n$-heksana, serta kertas saring biasa dan kertas saring Whatman no 1. Biji pala ini kemudian diekstrak untuk diambil butter pala untuk dienkapsulasi. Sedangkan bahan-bahan yang dibutuhkan untuk proses enkapsulasi yakni terdiri dari butter pala hasil ekstraksi, maltodekstrin (DE 15-20) dan whey protein isolate (WPI) 90 sebagai bahan pengkapsul, aquades sebagai pelarut, dan bahan untuk analisis seperti larutan DPPH (Diphenyl Picryl Hidrasil) 0,06mM, metanol 99,98\%, etanol 96\%, dan kertas saring.

\section{Alat}

Alat yang digunakan dalam penelitian ini adalah ultrasonic cleaner UC-10HD, rotary vacuum evaporator, homogenizer, vacuum oven, moisture balance, aw meter, chromameter, hot plate, spektrofotometer, oven, timbangan analitik, blender, kuvet, erlenmeyer, beaker glass, tabung reaksi, corong, kertas saring kecil (Whatman no 1), kertas saring besar, pengaduk, tabung kaca, sendok, dan loyang kaca.

\section{Tahapan Penelitian}

\section{Ekstraksi Biji Pala (Budianto, 2019)}

Biji pala yang telah kering kemudian dipotong kecil-kecil dan dihaluskan dengan blender sampai bubuk pala lolos ayakan mesh 36. Sebanyak 28 gram pala ditambahkan $100 \mathrm{ml}$ n-heksana pada erlenmeyer. Kemudian diekstrak dengan ultrasonic cleaner pada suhu $45^{\circ} \mathrm{C}$ dengan waktu 37,5 menit. Kemudian sampel disaring kertas saring besar dan kertas saring Whatman no 1 yang dijadikan satu. Sesudah disaring, filtrat yang didapatkan diuapkan dengan menggunakan rotary vacuum evaporator (suhu $40^{\circ} \mathrm{C}, 52 \mathrm{rpm}, \mathrm{P}=$ $0,09 \mathrm{MPa}, \mathrm{t}=5$ menit per $100 \mathrm{ml}$ filtrat) untuk menguapkan pelarut n-heksana dan mendapatkan butter pala.

\section{Enkapsulasi dengan Vacuum Drying (Yuniarti et al., 2013 dimodifikasi)}

Pertama-tama dilakukan penimbangan bahan sesuai dengan formulasi (bahan inti : penyalut $=1$ : 2)(Yuniarti et al., 2013). Maltodekstrin, WPI dan air dihomogenizer dengan kecepatan sesuai dengan formulasi selama 15 menit. Kemudian, butter pala dimasukkan kedalamnya dan dihomogenkan kembali selama 10 menit. Setelah itu, adonan dituangkan dalam loyang kaca dan dimasukkan dalam oven vakum selama 48 jam dengan suhu $50^{\circ} \mathrm{C}$ dan tekanan $0,5 \mathrm{~atm}$. Setelah 48 jam, hasil dikeluarkan dari oven dan dihaluskan dengan menggunakan blender.

Tabel 1 Formulasi Enkapsulat Butter Pala

\begin{tabular}{ccccc}
\hline Butter Pala (gr) & Maltodekstrin (gr) & WPI (gr) & Air $(\mathrm{ml})$ & Kecepatan Homogenisasi (rpm) \\
\hline 4 & 2 & 6 & 16 & 3000 \\
4 & 4 & 6 & 16 & 3000 \\
4 & 6 & 6 & 16 & 3000 \\
4 & 2 & 6 & 16 & 3500 \\
4 & 4 & 6 & 16 & 3500 \\
4 & 6 & 6 & 16 & 3500 \\
4 & 2 & 6 & 16 & 4000 \\
4 & 4 & 6 & 16 & 4000 \\
4 & 6 & 6 & 16 & 4000 \\
\hline
\end{tabular}


Metode penelitian menggunakan metode eksperimental dengan Rancangan Acak Lengkap sebanyak tiga kali ulangan yang terdiri dari dua faktor, yakni kecepatan homogenisasi (3000, 3500, dan $4000 \mathrm{rpm}$ ) dan konsentrasi maltodekstrin (MD : butter pala $=2: 4,4: 4,6: 4)$.

\section{Analisa Pengukuran Warna CIELab (Pomeranz \& Clifton, 1995)}

Analisa pengukuran warna dilakukan dengan menggunakan alat chromameter. Alat chromameter dikalibrasi terlebih dahulu dengan plat putih. Kemudian sampel bubuk enkapsulat dimasukkan pada plastik bening, plastik yang digunakan tidak boleh kusut. Hasil dari pengukuran dari analisa warna didapatkan nilai L* (lightness), a* (redness : green to red), dan $\mathrm{b}^{*}$ (yellowness : blue to yellow).

\section{Analisa Kadar Air (Lindani, 2016 dimodifikasi)}

Analisa kadar air dilakukan mengacu pada metode Lindani (2016) yang dimodifikasi pada bagian jumlah sampel dan lama waktu pengujian. Sebanyak 0,5 gram sampel dimasukkan ke dalam moisture analyzer, kemudian sampel diratakan di atas pan kemudian alat ditutup kembali dan ditunggu selama 10 menit. Hasil yang didapatkan kemudian dicatat.

Analisa Aktivitas Air (Saenab et al., 2010)

Analisa aktivitas air diuji dengan menggunakan Aw meter. Pertama-tama sampel enkapsulat dimasukkan dalam 1/2 wadah plastik dari Aw meter lalu ditunggu selama 15 menit. Hasil yang diperoleh kemudian dicatat.

\section{Analisa Antioksidan (Hussein et al., 2017)}

Sebanyak 0,5 gram bubuk enkapsulat dilarutkan dengan $5 \mathrm{ml}$ metanol 99,98\% dan didiamkan selama 2 jam. Kemudian sebanyak $0,1 \mathrm{ml}$ filtrat sampel direaksikan dengan 3,9 ml larutan DPPH 0,06 $\mathrm{mM}$ ke dalam tabung reaksi dan divortex. Sampel kemudian didiamkan selama 30 menit dalam ruang gelap. Kemudian dilakukan pengukuran absorbansi dengan spektrofotometer UV-Vis $(\lambda=517 \mathrm{~nm})$. Untuk larutan blanko dibuat dengan mengganti larutan sampel dengan metanol $(0,1 \mathrm{ml})$. Aktivitas antioksidan diketahui dari perhitungan dengan rumus:

Aktivitas Antioksidan $(\%)=$

$\left[\frac{\text { absorbansi blanko-absorbansi sampel }}{\text { absorbansi blanko }}\right] \times 100 \%$

\section{HASIL DAN PEMBAHASAN}

\section{Pengukuran Warna CIELab Enkapsulat Pala}

Nilai kecerahan enkapsulat butter pala

Berdasarkan Tabel 2, terdapat beda nyata pada tingkat kepercayaan $95 \%(\alpha=0,05)$ hanya pada penggunaan kecepatan homogenisasi $3000 \mathrm{rpm}$ antara penambahan maltodekstrin 6 gram dengan maltodekstrin 2 gram dan 4 gram. Nilai L (lightness) berhubungan dengan derajat kecerahan, yang berkisar antara nol sampai seratus pada alat kromameter. Nilai L yang mendekati 100 menunjukkan sampel yang dianalisis memiliki kecerahan tinggi (terang) sedangkan nilai $\mathrm{L}$ yang mendekati nol menunjukkan sampel memiliki kecerahan rendah (gelap). Nilai L pada penelitian ini menunjukkan bubuk enkapsulat termasuk cukup cerah (terang). Pada penelitian ini, semakin besar penambahan maltodekstrin, nilai L semakin meningkat. Menurut Yuliawaty \& Susanto (2015), konsentrasi maltodekstrin yang semakin banyak akan memberikan warna yang cenderung terang, hal ini karena maltodekstrin berwarna putih dan makin banyaknya total padatan. Perbedaan kecepatan homogenisasi tidak menunujukkan adanya perbedaan nyata pada tingkat kepercayaan $\quad 95 \% \quad(\alpha=0,05)$ antarsampel. 
Tabel 2 Nilai Kecerahan Enkapsulat Butter Pala

\begin{tabular}{|c|c|c|c|}
\hline \multirow{2}{*}{ Kecepatan Homogenisasi (rpm) } & \multicolumn{3}{|c|}{ Maltodekstrin (gram) } \\
\hline & 2 & 4 & 6 \\
\hline 3000 & $88,247^{\mathrm{aA}} \pm 0,280$ & $87,475^{\mathrm{aA}} \pm 0,479$ & $90,620^{\mathrm{bA}} \pm 0,653$ \\
\hline 3500 & $86,747^{\mathrm{aA}} \pm 0,945$ & $88,717^{\mathrm{aA}} \pm 1,708$ & $88,677^{\mathrm{aA}} \pm 1,354$ \\
\hline 4000 & $88,892^{\mathrm{aA}} \pm 0,373$ & $88,177^{\mathrm{aA}} \pm 0,833$ & $89,902^{\mathrm{aA}} \pm 0,350$ \\
\hline
\end{tabular}

Keterangan:

1. Semua nilai merupakan nilai mean \pm standar deviasi

2. Nilai dengan huruf yang berbeda antar kolom menunjukkan ada beda nyata antar perlakuan maltodekstrin pada tingkat kepercayaan 95\% $(<0,05)$ berdasarkan uji One Way Anova dengan uji Duncan sebagai uji beda

3. Nilai dengan huruf kapital yang berbeda antar baris menunjukkan ada beda nyata antar perlakuan kecepatan homogenisasi pada tingkat kepercayaan 95\% $(<0,05)$ berdasarkan uji One Way Anova dengan uji Duncan sebagai uji beda

Nilai redness (green to red) enkapsulat butter pala

Berdasarkan Tabel 3, nilai a merupakan warna campuran merah hijau. Nilai a positif antara 0-60 untuk warna merah sedangkan a negatif antara 0-(-60) untuk warna hijau. Nilai $a^{*}$ pada penelitian ini menunjukkan bubuk enkapsulat termasuk berwarna sedikit

merah karena dihasilkan nilai $\mathrm{a}^{*}$ positif. Penurunan nilai $\mathrm{a}^{*}$ terjadi seiring dengan meningkatnya penambahan maltodekstrin. Hal ini terjadi karena maltodekstrin memiliki warna putih yang akan menurunkan warna kemerahan pada enkapsulat butter biji pala (Yuliawaty \& Susanto, 2015).

Tabel 3 Nilai Redness Enkapsulat Butter Pala

\begin{tabular}{cccc}
\hline \multirow{2}{*}{ Kecepatan Homogenisasi (rpm) } & \multicolumn{3}{c}{ Maltodekstrin (gram) } \\
\cline { 2 - 4 } & 2 & 4 & 6 \\
\hline 3000 & $1,215 \pm 0,036$ & $1,117 \pm 0,052$ & $0,225 \pm 0,050$ \\
3500 & $1,490 \pm 0,143$ & $0,880 \pm 0,155$ & $0,625 \pm 0,084$ \\
4000 & $1,015 \pm 0,030$ & $0,853 \pm 0,090$ & $0,408 \pm 0,043$ \\
\hline
\end{tabular}

Keterangan:

1. Semua nilai merupakan nilai mean \pm standar deviasi

Nilai yellowness (blue to yellow) enkapsulat butter pala

Berdasarkan Tabel 4, terjadi perbedaan nyata pada tingkat kepercayaan $95 \%$ $(\alpha=0,05)$ pada penggunaan kecepatan homogenisasi $3000 \mathrm{rpm}$ antara penambahan maltodekstrin sebanyak 2 gram dengan maltodekstrin 4 gram dan 6 gram. Nilai b merupakan warna campuran biru-kuning. Nilai $\mathrm{b}^{+}$antara 0-60 untuk warna kuning

sedangkan nilai $\mathrm{b}^{-}$antara 0-(-60) untuk warna biru. Penurunan nilai b* menunjukkan warna kuning semakin menurun namun masih cenderung warna kuning karena nilai b yang diperoleh bernilai positif. Warna kuning didapatkan dari sampel butter biji pala dan WPI yang berwarna kuning, sedangkan penurunan warna kuning disebabkan oleh adanya maltodekstrin yang berwarna putih (Yuliawaty \& Susanto, 2015).

Tabel 4 Nilai Yellowness b* Enkapsulat Butter Pala

\begin{tabular}{cccc}
\hline \multirow{2}{*}{ Kecepatan Homogenisasi (rpm) } & 2 & 4 & 6 \\
\cline { 2 - 4 } & $25,700^{\mathrm{cA}} \pm 0,231$ & $23,465^{\mathrm{bAB}} \pm 1,131$ & $21,535^{\mathrm{aA}} \pm 0,234$ \\
3000 & $23,942^{\mathrm{aA}} \pm 0,235$ & $22,938^{\mathrm{aA}} \pm 0,581$ & $22,302^{\mathrm{aA}} \pm 0,544$ \\
3500 & $22,533^{\mathrm{aA}} \pm 0,232$ & $24,572^{\mathrm{aB}} \pm 0,282$ & $22,145^{\mathrm{aA}} \pm 0,395$ \\
\hline
\end{tabular}

Keterangan:

1. Semua nilai merupakan nilai mean \pm standar deviasi

2. Nilai dengan huruf yang berbeda antar kolom menunjukkan ada beda nyata antar perlakuan maltodekstrin pada tingkat kepercayaan 95\% (<0,05) berdasarkan uji One Way Anova dengan uji Duncan sebagai uji beda

3. Nilai dengan huruf kapital yang berbeda antar baris menunjukkan ada beda nyata antar perlakuan kecepatan homogenisasi pada tingkat kepercayaan $95 \%(<0,05)$ berdasarkan uji One Way Anova dengan uji Duncan sebagai uji beda 


\section{Kadar Air Enkapsulat Pala}

Kadar air bahan pangan merupakan banyaknya air yang terdapat dalam suatu bahan pangan yang dinyatakan dalam persentase (Ulfindrayani \& A'yuni, 2018). Semakin rendah kadar air dalam suatu bahan pangan, maka pertumbuhan bakteri atau jamur penyebab kerusakan akan semakin menurun (Purnomo et al., 2014). Berdasarkan Tabel 5, kadar air didapatkan pada range 6,912 $\pm 0,354 \%$ hingga 7,788 \pm $0,141 \%$ Menurut SNI, batas maksimal kadar air bubuk bumbu rempah 01-3709-1995 adalah 12\%, maka hasil bubuk enkapsulat butter pala yang dihasilkan masih masuk dalam syarat SNI.

Berdasarkan Tabel 5, pada penambahan 2 gram maltodekstrin, kadar air akan menurun seiring meningkatnya kecepatan homogenisasi. Hal ini sesuai dengan teori Tanjung (2013), bahwa proses homogenisasi dengan kecepatan tinggi akan menurunkan tegangan permukaan larutan dan mengubah ukuran partikel droplet menjadi lebih kecil sehingga akan memperluas permukaan partikel.

Tabel 5 Kadar Air (\%) Enkapsulat Butter Pala

\begin{tabular}{cccc}
\hline \multirow{2}{*}{ Kecepatan Homogenisasi $(\mathrm{rpm})$} & 2 & 4 & \multicolumn{3}{c}{ Maltodekstrin (gram) } \\
\cline { 2 - 4 } & $7,788^{\mathrm{aB}} \pm 0,141$ & $7,232^{\mathrm{aA}} \pm 0,414$ & $7,477^{\mathrm{aA}} \pm 0,154$ \\
3000 & $7,470^{\mathrm{aAB}} \pm 0,429$ & $7,223^{\mathrm{aA}} \pm 0,331$ & $7,605^{\mathrm{aA}} \pm 0,306$ \\
3500 & $6,912^{\mathrm{aA}} \pm 0,354$ & $7,587^{\mathrm{bA}} \pm 0,240$ & $7,560^{\mathrm{bA}} \pm 0,330$ \\
\hline
\end{tabular}

Keterangan:

1. Semua nilai merupakan nilai mean \pm standar deviasi

2. Nilai dengan huruf yang berbeda antar kolom menunjukkan ada beda nyata antar perlakuan maltodekstrin pada tingkat kepercayaan 95\% (<0,05) berdasarkan uji One Way Anova dengan uji Duncan sebagai uji beda

3. Nilai dengan huruf kapital yang berbeda antar baris menunjukkan ada beda nyata antar perlakuan kecepatan homogenisasi pada tingkat kepercayaan 95\% $(<0,05)$ berdasarkan uji One Way Anova dengan uji Duncan sebagai uji beda

Namun, dengan berubahnya partikel droplet menjadi lebih kecil akan mempercepat penguapan pelarut (air) sehingga viskositas larutan akan meningkat, dan menyebabkan partikel satu dengan yang lain akan mudah menempel sehingga ukuran partikel menjadi lebih besar (aglomerasi). Disamping itu, dikuatkan juga dengan teori Sari dan Lestari (2015), bahwa droplet yang mengecil akan meningkatkan jumlah droplet dalam fase air sehingga kecepatan perpindahan droplet juga akan menurun dan meningkatkan jumlah protein yang ada pada permukaan sehingga viskositas akan meningkat (Samani \& Naji, 2019).

Menurut Hayati et al. (2015), penambahan maltodekstrin dapat menurunkan kadar air karena ada peningkatan total padatan. Meningkatnya maltodekstrin sampai batas tertentu akan mempercepat penguapan air suatu bahan pangan pada saat dilakukan pengeringan. Semakin besar total padatan dalam bahan yang dikeringkan, akan menurunkan jumlah air yang harus dievaporasi (Purnomo et al., 2014). Laju penguapan air yang cepat ini dikarenakan air yang berada pada maltodekstrin lebih mudah untuk diuapkan dibanding air yang berada pada bahan (Paramita et al., 2015). Disamping itu, maltodekstrin merupakan bahan yang bersifat higroskopis, sehingga maltodekstrin mampu mengikat air. Menurut Goula \& Adamopoulos (2008), penambahan maltodekstrin yang terlalu banyak akan membuat maltodekstrin menjadi menggumpal sehingga molekul air yang akan berdifusi terhalang oleh molekul maltodekstrin yang lebih besar dan akan menurunkan laju pengeringan. Teori ini dapat dibuktikan dengan terjadinya peningkatan kadar air pada penambahan maltodekstrin sebesar 6 gram.

\section{Aktivitas Air Enkapsulat Pala}

Aktivitas air (Aw) merupakan jumlah air bebas yang digunakan mikroorganisme untuk bertumbuh. Aktivitas air memiliki range antara 0-1 (Belitz et al., 2009). Setiap mikroorganisme memiliki nilai aw minimal untuk membuatnya tumbuh dengan baik seperti kapang akan tumbuh baik pada Aw 0,6 - 0,7(Belitz et al., 2009). Dari teori 
tersebut, dapat dikatakan bahwa produk enkapsulasi butter biji pala dapat rusak oleh kapang.

Peningkatan aktivitas air pada bubuk enkapsulat dengan penambahan konsentrasi maltodekstrin dapat disebabkan oleh kemampuan maltodekstrin dan whey protein isolate dalam mengikat air. Kemampuan mengikat air dipengaruhi oleh adanya senyawa protein didalam WPI. Menurut Rustad et al., (1983), semakin berkurangnya kandungan air maka jarak antara ikatan protein pendek, sehingga akan memperketat Tabel 6 Aktivitas Air Enkapsulat Butter Pala

\begin{tabular}{cccc}
\hline Kecepatan Homogenisasi & \multicolumn{3}{c}{ Maltodekstrin (gram) } \\
\cline { 2 - 4 }$(\mathrm{rpm})$ & 2 & 4 & 6 \\
\hline 3000 & $0,626^{\mathrm{bB}} \pm 0,018$ & $0,570^{\mathrm{aA}} \pm 0,041$ & $0,585^{\mathrm{aA}} \pm 0,003$ \\
3500 & $0,584^{\mathrm{aB}} \pm 0,031$ & $0,573^{\mathrm{aA}} \pm 0,038$ & $0,583^{\mathrm{aB}} \pm 0,043$ \\
4000 & $0,566^{\mathrm{aA}} \pm 0,001$ & $0,584^{\mathrm{bA}} \pm 0,032$ & $0,579^{\mathrm{aA}} \pm 0,003$ \\
\hline
\end{tabular}

\section{Keterangan:}

1. Semua nilai merupakan nilai mean \pm standar deviasi

2. Nilai dengan huruf yang berbeda antar kolom menunjukkan ada beda nyata antar perlakuan maltodekstrin pada tingkat kepercayaan 95\% (<0,05) berdasarkan uji One Way Anova dengan uji Duncan sebagai uji beda

3. Nilai dengan huruf kapital yang berbeda antar baris menunjukkan ada beda nyata antar perlakuan kecepatan homogenisasi pada tingkat kepercayaan $95 \%(<0,05)$ berdasarkan uji One Way Anova dengan uji Duncan sebagai uji beda

\section{Aktivitas Antioksidan Enkapsulat Pala}

Pengujian aktivitas antioksidan menjadi sangat penting, karena pala memiliki kandungan antioksidan alami yang tinggi. Senyawa fitokimia butter pala yang memiliki antioksidan tinggi yakni senyawa myristicin, isoeugenol, dan eugenol (Ginting et al., 2017). Sehingga dari hasil enkapsulat dapat dilihat apakah setelah proses enkapsulasi, serbuk enkapsulat butter pala masih memiliki aktivitas antioksidan yang cukup tinggi atau menurun drastis.

Antioksidan merupakan suatu senyawa yang memiliki kemampuan dalam mencegah reaksi radikal bebas pada oksidasi lipid. jaringan protein dan meningkatkan kemampuan pengikatan air. Dalam satu gram protein terkandung 0,3-0,5 gram air dan sekitar 4-9\% dari air yang berikatan dengan protein teradsorpsi pada permukaan protein. Ikatan air yang teradsorbsi pada permukaan protein bersifat lemah (Hardman, 1989). Nilai Aw yang semakin tinggi akan membuat daya simpan produk menjadi lebih singkat dan sebaliknya, nilai Aw yang semakin rendah memiliki nilai simpan yang lebih panjang (Belitz et al., 2009).

Tabel 7 Aktivitas Antioksidan (\%) Enkapsulat Butter Pala

\begin{tabular}{cccc}
\hline Kecepatan Homogenisasi & \multicolumn{3}{c}{ Maltodekstrin (gram) } \\
\cline { 2 - 4 }$(\mathrm{rpm})$ & 2 & 4 & 6 \\
\hline 3000 & $94,598 \pm 0,205$ & $91,453 \pm 1,005$ & $94,210 \pm 0,251$ \\
3500 & $92,418 \pm 1,182$ & $93,095 \pm 1,138$ & $91,268 \pm 2,223$ \\
4000 & $94,528 \pm 0,101$ & $88,665 \pm 3,180$ & $94,452 \pm 0,204$ \\
\hline
\end{tabular}

Keterangan:

Radikal bebas adalah suatu gugus atom yang memiliki elektron tidak berpasangan sehingga bersifat reaktif (Ahmad, Mun, \& Elya, 2012). Dalam penelitian ini, metode uji aktivitas antioksidan yang dilakukan ialah metode DPPH (1,1-Diphenyl-2-Picryl Hydrazyl). Dalam pengujiannya, sampel yang sudah dicampur dengan DPPH akan terjadi perubahan warna dari ungu menjadi kuning bila terdapat aktivitas antioksidan dalam sampel. Perubahan warna terjadi saat atom hidrogen pada antioksidan berpasangan dengan elektron tunggal yang terdapat dalam DPPH (Permana et al., 2003).

1. Semua nilai merupakan nilai mean \pm standar deviasi 
Menurut Hartiati \& Mulyani (2015), pada konsentrasi penambahan maltodekstrin tertentu akan membuat kualitas antioksidan semakin baik dan kemampuan menangkap radikal bebas yang semakin baik, karena maltodekstrin dapat menurunkan viskositas dan memiliki sifat untuk mencegah terjadinya oksidasi sehingga antioksidan akan terselimuti dengan baik. Pengunaan penyalut maltodekstrin memiliki sifat ketahanan oksidasi yang tinggi dan dapat menurunkan viskositas emulsi dan dikombinasikan dengan whey protein isolate yang memiliki sifat pengemulsi yang baik menyebabkan senyawa antioksidan dalam mikroenkapsulan dapat terselimuti dan terlindungi dengan baik (Purnomo et al., 2014). Hal ini dapat dibuktikan dari adanya kenaikan aktivitas antioksidan yang terukur bila maltodekstrin yang ditambahkan sebesar 6 gram. Disamping itu, peningkatan kecepatan homogenisasi akan meningkatkan aktivitas antioksidan, hal ini terjadi karena semakin cepatnya kecepatan homogenisasi maka viskositas akan meningkat dan emulsi yang terbentuk semakin stabil. Stabilnya emulsi akan membuat emulsi tidak cepat berpisah sehingga antioksidan masih tersalut dengan baik (Kailaku et al., 2012).

\section{KESIMPULAN}

Berdasarkan penelitian, maka dapat disimpulkan bahwa formula enkapsulat butter pala optimum yakni pada konsentrasi maltodekstrin 2 gram dan kecepatan homogenisasi $3000 \mathrm{rpm}$. Ini dipilih karena aktivitas antioksidan yang tertinggi didapatkan sebesar 94,598\%, kadar air bubuk enkapsulat 7,788\% (sesuai standar SNI $<12 \%$ ), aktivitas air 0,626, serta didapatkan warna bubuk kuning cerah (nilai $\mathrm{L}^{*}=$ 88,247 , nilai $\mathrm{a}^{*}=1,215$, dan nilai $\mathrm{b}^{*}=25,7$ ). Konsentrasi maltodektrin dan kecepatan homogenisasi berbeda nyata $(\alpha<0,05)$ terhadap nilai warna $b^{*}$ dan aktivitas air, namun tidak berbeda nyata $(\alpha>0,05)$ terhadap kadar air dan warna $L^{*}$.

\section{UCAPAN TERIMA KASIH}

Penulis mengucapkan terima kasih kepada semua pihak yang telah berkontribusi membantu dalam penelitian ini, terutama atas pendanaan oleh DIKTI dengan SK No. 010/L6/AK/SP2H.1/PENELITIAN/2019.

\section{DAFTAR PUSTAKA}

Ahmad, A. R., Mun, A., \& Elya, B. (2012). Study of Antioxidant Activity With Reduction of DPPH Radical and Xanthine Oxidase Inhibitor of the Extract of Ruellia Tuberosa Linn Leaf. International Research Journal of Pharmacy, 3(11), 66-70. Diakses dari http://staff.ui.ac.id/system/files/users/abdul. munim61/publication/munimpub32.pdf

Belitz, H. D., Grosch, W., \& Schieberle, P. (2009). Food Chemistry. In Encyclopedia of Microbiology. Diakses dari https://www.academia.edu/23725260/Food _Chemistry_4th_Edition_by_Belitz_W._Gr osch_P._Schieberle_1

Budianto, V. (2019). Optimasi Suhu, Waktu, dan Rasio Bahan Terhadap Hasil Ekstraksi Serta Karakteristik Oleoresin Biji Pala (Myristica fragrans) Menggunakan Pelarut $N$-Heksana Dengan Metode Ekstraksi UAE. SKRIPSI. Universitas Katolik Soegijapranata. Semarang.

Cahyadi, K. (2017). Pengaruh Metode Spray Drying Dan Foam-Mat Drying Terhadap Karakteristik Fisikokimia Dan Wortel the Effect of Spray Drying and Foam-Mat Drying Methods on Physicochemical Characteristics of Instant Powder Drink of Mixed Pumpkin and Carrots. Skripsi Fakultas Teknologi Pertanian Unika Soegijapranata Semarang.

Gardjito, M., Murdiati, A., \& Aini, N. (2006). Mikroenkapsulasi $\beta$ - Karoten Buah Labu Kuning dengan Enkapsulasn Whey dan Karbohidrat. Jurnal Teknologi Pertanian, 2(1), 13-18. Diakses dari https://jtpunmul.files. wordpress.com/2013/0 2/vol-21-3-murdijati-gardjito-et-al.pdf

Goula, A. M., \& Adamopoulos, K. G. (2008). Effect of Maltodextrin Addition During Spray Drying of Tomato Pulp in Dehumidified Air: II. Powder Properties. Drying Technology, 26, 726-737. Diakses dari 
https://doi.org/10.1080/0737393080204637 7

Hardman, T.M. 1989. Water and Food Quality. Elsevier Science Publiser LTD. USA. P 145-152.

Hartiati, A., \& Mulyani, S. (2015). The Effect of Maltodextrin Concentration and Drying Temperature to Antioxidant Content of Sinom Beverage Powder. Agriculture and Agricultural Science Procedia,

3, 231-234. Diakses dari https://doi.org/10.1016/j.aaspro.2015.01.04 5

Hayati, H. R., Dewi, A. K., Nugrahani, R. A., \& Satibi, L. (2015). Pengaruh Konsentrasi Maltodekstrin Terhadap Kadar Air dan Waktu Melarutnya Santan Kelapa Bubuk (Coconut Milk Powder) Dalam Air. Jurnal Teknologi, 7(1), 55-60. Diakses dari DOI: 10.24853/jurtek.7.1.55-60

Hussein, A. M. S., Kamil, M. M., Lotfy, S. N., Mahmoud, K. F., Mehaya, F. M., \& Mohammad, A. A. (2017). Influence of Nano-encapsulation on Chemical Composition, Antioxidant Activity and Thermal Stability of Rosemary Essential Oil. American Journal of Food Technology, 12(3), 170-177. Diakses dari https://doi.org/10.3923/ajft.2017.170.177

Kailaku, S. I., Hidayat, Tatang., \& Setiabudy. D. A. (2012). Pengaruh Kondisi Homogenisasi Terhadap Karakteristik Fisik dan Mutu Santan Selama Penyimpanan. Jurnal Littri. Vol 18 (1). 31- 39. Diakses dari Diakses dari

http://dx.doi.org/10.21082/littri.v18n1.2012 $.31 \% 20-\% 2039$

Lindani, A. (2016). Perbandingan Pengukuran Kadar Air Metode Moisture Analyzer Dengan Metode Oven Pada Produk Biskuit Sandwich Cookies Di Pt Mondelez Indonesia Manufacturing. SKRIPSI. Institut Pertanian Bogor. Bogor. Diakses dari http://repository.ipb.ac.id/handle/12345678 9/86635

Muchtadi, Tien R; Ilma, Alfia Nurul; Hunaefi, Dase; Yuliani, S. (2015). Kondisi Homogenisasi dan Prapeningkatan Skala Proses Mikroenkapsulasi Minyak Sawit. Jurnal Teknologi Industri Pertanian, 25(3), 248-259. Diakses dari https://journal.ipb.ac.id/index.php/jurnaltin/ article/view/11792
Nurdjannah, N., Mulyono, E., \& Risfaheri. (2007). Teknologi Pengolahan Pala. Diakses dari http://pascapanen.litbang.pertanian.go.id/as sets/media/publikasi/juknis_pala.pdf

Paramita, I. A. M. I., Mulyani, S., \& Hartiati, A. (2015). Pengaruh Konsentrasi Maltodekstrin Dan Suhu Pengeringan Terhadap Karakteristik Bubuk Minuman Sinom. Jurnal Rekayasa Dan Manajemen Agroindustri, 3(2), 58-68. Diakses dari https://ojs.unud.ac.id/index.php/jtip/article/ view/18690

Permana, D., Lajis, N. H., Abas, F., Othman, A. G., Ahmad, R., Kitajima, M., Takayama, H., \& Aimi, N. (2003). Antioxidative Constituents of Hedyotis Diffusa Willd. Natural Product Sciences, 9(1), 7-9. Diakses dari https://www.researchgate.net/publication/23 3818619_Antioxidative_Constituents_of_H edyotis_diffusa_Willd

Pomeranz, Yeshajahu; Meloan, Clifton, E. (1995). Food Analysis Theory And Practice.In The British Journal of Psychiatry Vol. 112. Diakses dari https://doi.org/10.1192/bjp.112.483.211-a

Purnomo, W., Khasanah, L. U., \& Anandito, B. K. (2014). Pengaruh Ratio Kombinasi Maltodekstrin, Karagenan dan Whey Terhadap Karakteristik Mikroenkapsulan Pewarna Alami Daun Jati (Tectona Grandis L. F.). Jurnal Aplikasi Teknologi Pangan, 3(3), 121-129. Diakses dari http://journal.ift.or.id/files/33121129

Rustad, T. and Nesse, N. 1983. Heat Treatment and Drying of Capelin Mince, Effect of Water Binding and Soluble Protein. Journal Food Science 48, 1320-2, 1347

Saenab, Andi., Laconi, E. B., Retanani, Yuli., \& Mas'ud, M. S. (2010). Evaluasi Kualitas Pelet Ransum Komplit yang Mengandung Produk Samping Udang. JITV. Vol 15 (1). 31-39. Diakses dari https://docplayer.info/32894257-Evaluasikualitas-pelet-ransum-komplit-yangmengandung-produk-samping-udang.html

Samani, S. A., \& Naji, M. H. (2019). Effect of Homogenizer Pressure and Temperature on Physicochemical, Oxidative Stability, Viscosity, Droplet Size, and Sensory Properties of Sesame Vegetable Cream. Food Science and Nutrition, 1-8. Diakses dari https://doi.org/10.1002/fsn3.680 
Sheu, T. Y., \& Rosenberg, M. (1998). Microstructure of Microcapsules Consisting of Whey Proteins and Carbohydrates. Journal of Food Science, 63(3), 491-494. Diakses dari https://doi.org/10.1111/j.13652621.1998.tb15770.x

Tanjung, Yenni Puspita. (2013). Formulasi, Evaluasi, Serta Uji Sitotoksik Terhadap Sel Kanker MCF-7 dari Sistem Nanopartikel Polimerik Polyvinyl Pyrrolidone Dengan Zat Aktif Kurkumin. IJAS Vol 3 Nomor 3. Desember 2013. Diakses dari http://jurnal.unpad.ac.id/ijas/article/downloa d/15055/7124

Ulfindrayani, I. F., \& A'yuni, Q. (2018). Penentuan Kadar Asam Lemak Bebas Dan Kadar Air Pada Minyak Goreng Yang Digunakan Oleh Pedagang Gorengan Di Jalan Manyar Sabrangan, Mulyorejo, Surabaya. Journal of Pharmacy and Science, 3(2), 17-22. Diakses dari https://pdfs.semanticscholar.org/0c13/02d8 5e702a029ef24bb9d1e685ec5bd3f9da.pdf

Yuliasari, Shannora; Dedi Fardiaz; Nuri Andarwulan; Sri Yuliani. (2016). Karakteristik Enkapsulat Minyak Sawit Merah dengan Pengayaan Betakaroten. Jurnal Informatika Pertanian Vol 25 Nomor 1, Juni 2016: 107-116. Diakses dari https://pdfs.semanticscholar.org/db66/60b4 6016c194bb54e3fcaa8487aaffe5d7b6.pdf

Yuliawaty, S. T., \& Susanto, W. H. (2015). Pengaruh Lama Pengeringan dan Konsentrasi Maltodekstrin terhadap Karakteristik Fisik Kimia dan Organoleptik Minuman Instan Daun Mengkudu (Morinda citrifolia L). Jurnal Pangan Dan Agroindustri, 3(1), 41-51. Diakses dari https://jpa.ub.ac.id/index.php/jpa/article/vie w/108

Yuniarti, Desy Windia; Sulistiyati, Titik Dwi; Suprayitno, E. (2013). Pengaruh Suhu Pengeringan Vakum terhadap Kualitas Serbuk Albumin Ikan Gabus (Ophiocephalus striatus). Student Journal, 1(1), 1-11. Diakses dari http://thpi.studentjournal.ub.ac.id/index.php /thpi/article/view/1

Zhao, C. Y., \& Zhang, G. H. (2011). Review on Microencapsulated Phase Change Materials (MEPCMs): Fabrication, Characterization and Applications. Renewable and Sustainable Energy
Reviews, 15(8),3813-3832. Diakses dari https://doi.org/10.1016/j.rser.2011.07.019 